\title{
The Transformation of Mbaru Gendang from Communal-Cultural House to Cultural Building in Manggarai, Eastern Indonesia
}

\author{
Fransiska Widyawati \\ \{fwidyawati10@gmail.com\} \\ Universitas Katolik Indonesia Santu Paulus Ruteng ${ }^{1}$
}

\begin{abstract}
Mbaru gendang is a traditional-communal house of the Manggarai people in Eastern Indonesia. It functions as a sacred place, symbol of continuity over generations, and the center of a village. The house has become the home for the village heads. They have been responsible for maintaining the house, its relationship with the ancestors/spirits and ensuring the house's social, cultural, and religious functions. However, this previous study found some houses have become empty buildings as village heads had no longer dwelled in the houses. This research explored the causes and consequences of the phenomenon. It employed ethnography as the method with an in-depth interview as a tool for collecting the data. The study found several reasons why the village and clan head did not want to live in the house: living in their own house is more comfortable, private, economical, confident than living in the communal one. In addition, there are conflicts between families and a new agreement from residents about the house. Although this change has not been following the old custom, many parties can rationalize this change without losing their cultural identity. There have always been new negotiations and adaptations in the culture.
\end{abstract}

Keywords: Manggarai, Traditional House, Cultural Changes, Home

\section{Introduction}

Studies about the traditional house have attracted many scholars around the world. Some of which have interested in exploring traditional houses in Malaysia (Rasdi, 2005), in China (Liangwen, 2006) (Knapp RG, 2012), in Turkey (Dalkılıç \& Nabikoğlu, 2020), in Kurds (Akram, OK, Franco, DJ, \& Ismail, 2016) and or Nicosia (Gunce Kagan and Damla Misirlisoy, 2019). Most of these studies have emphasized on cultural heritage aspect of the house. People and the government have been encouraged to maintain the house. Other studies have been interested in the house as a cultural symbols and identity (Mackey, 2002) (Milligan, 2003). Some scholars have connected their study with the tourism industry and promotion, which influences the house's existence (TIMOTHY, 2021) (Du Cros, H \& McKercher, 2014).

A similar study of traditional houses in Indonesia as cultural heritage, cultural identity, and its changes in modern times has also attracted the attention of domestic and foreign scholars. Among them have been done in Sunda (Darmayanti, 2016), Jogyakarta (Adishakti, 2008), Minangkabau (Noviarti et al., 2013), Tana Toraja (Adams, 2003), Bandar Lampung (Hardilla \& Nugroho, 2018), and Batak Toba (Hanan et al., 2015). The scholars pointed out the urgency of maintaining traditional houses as cultural heritage and identity. However, those studies 
emphasized the unavoidable changes toward the way local people perceived and their attitude toward their culture, including their traditional house due to their new way of life.

This research wanted to take part in this issue. The focus was on the mbaru gendang of the Manggarai people in Flores, East Nusa Tenggara Province. Mbaru gendang is a traditionalcommunal house of the Manggarai people. Culturally, it functions as a sacred place, a symbol of continuity over generations, and as the center of a village. This great house has become the home for the village head and several clans' heads. They have been responsible for maintaining the house, ensuring the house's social, cultural, and religious functions, and maintaining the house's relationship with the ancestors and village spirits.

However, our initial study found a new phenomenon in this decade. Some houses have become empty buildings as village heads, or clan heads had no longer dwelled in the houses. This phenomenon is undoubtedly contrary to the Manggarain culture. Therefore, this fact is interesting to study. There are two main questions of the study: What were the causes of the change? What were the impacts on the local communities and the concepts of traditional houses?

This research was conducted on several traditional houses that have become empty around the town of Ruteng. It employed an ethnographic approach. The method of data collection was an in-depth interview. In order to keep respondents' identities secret, this article does not explicitly mention the name and village but in general terms only.

\section{Methodology}

\subsection{The Mbaru Gendang of The Manggaraian People}

Manggarai is one of the tribes living on the island of Flores in East Nusa Tenggara. Manggarai consists of three districts: the Manggarai, West Manggarai, and East Manggarai. The people have practiced their culture intensely. Allerton's study (Allerton, 2009) showed that even though most people have been affiliated with Catholicism since the early 20th century, the people still have deeply attached to their local beliefs. One of the essential cultural aspects belonging to the Manggarai people is their traditional house called mbaru gendang. Mbaru means house, and gendang means drum. In this big house, drums, the traditional musical instruments, using in various rituals and village parties, are hung. Of course, the drum can be owned by anyone and placed anywhere. However, the drums that are hung on the mbaru gendang are unique. They cannot be carried anywhere and can only be played at the communaltraditional house during special village ceremonies. They are sacred and have become a symbol of the village. Besides being called mbaru gendang, the house is also called mbaru tembong or mbaru niang. However, the term mbaru gendang is the most popular one (Erb Maribeth, 1999).

Generally, one village has only one mbaru gendang. Only a village that has autonomous power can have a house. The house is the headquarter of the village authoritative. Within this house, the village head and the representative of the village's clans live. They function as guardians of the house, village, and the whole village's relations with spirits and ancestors. When the village head dies, the eldest son automatically becomes the new village head. Then he will live in the house. Likewise, if the clans' representative dies, the eldest sons will automatically replace and live in the house. If the eldest sons cannot live inside the house for some reason, they can be replaced by other younger brothers, and so on. All of this follows a patriarchal system (Lon, 2015). 
Because several families live together in the house, mainly the house is large. However, one family can have only one private bedroom. Therefore, the number of private bedrooms has been adjusted to the number of clans in the village. This bedroom is the only family privacy room. Apart from the bedrooms, there is a large opened room called lutur. It has many functions: a place to receive guests, a dining room, and a room to hold ceremonies and village meetings. This expansive space can accommodate dozens of people. If the house is large, it can accommodate hundreds of people sitting in it. In this room, the older children of all families dwelling in the house sleep. Likewise, if there are guests, they also sleep here. If a family member dies, lutur also functions to put the body in the house. Besides the room, there is an open kitchen, where each family has a stone stove for cooking.

Mbaru gendang is a communal house belong to the village. It is not the private house of the village head or clan who resides in it. Every village resident should build or repair the house. The people function as representatives, courts, and hall rooms for meeting or doing rituals. People consider the whole part of the house as sacred. When people build it, they do a series of complex, mystical, and religious rituals. Each part of the house has a symbolic and religious meaning. There are three main parts of the house: the basement, living room, and attic. Basement symbolizes the underworld, darkness, and evil spirits. People keep their working equipment there. They also raise animals such as pigs, horses, chickens, and dogs there. The second part of the house is the family room or lutur, symbolizing the human world. People eat, sleep, play, pray, and do other human activities there. The third part is the attic which symbolizes the world of spirits. It is a place to put offerings to spirits and the ancestors (Allerton, 2003). The Manggarai people believe that each small part of the house has a definite religious symbolic meaning.

Exactly when the Manggarai people started owning mbaru gendang is unknown. They did not have a writing tradition; therefore, historical records were limited. When the Dutch colonialists and Catholic Church missionaries were present in Manggarai in the late 19th and early 20th centuries, they documented several pictures of the mbaru gendang. Some of the documentation could be found online from the website of the Tropen Museum, Netherlands. The existing documentations show the large shape of the house, inhabited by tens to hundreds of people. It had only one door and no windows. The house roof extended from the top to near the floor, functioning simultaneously as a house wall. This kind of house model could still be traced until the 1960s and specifically in Wae Rebo until the 1990s (Antar Yori, 2010).

In the early 20th century, a doctor from the Netherlands researched people's health. He found that worms attacked $100 \%$ of the Manggarai people. According to him, the giant, windowless, smoky, dirty Manggarai house was the cause of worms. Therefore, he recommended that the government prohibit people from living in the mbaru gendang and other large houses (Steenbrink K., 2007). As a result, since then, the Dutch government had encouraged and forced people to leave the traditional communal house and other big houses. The government instructed people to build tiny, modern, and more hygienic houses instead of big ones.

When the government constructed roads that connect one area to another, they insisted that people move from their villages to the new areas closing by the road. Initially, most villages were located on a hill (a village in the local language is called "golo"/hill), though terrain to construct the road. When people started to get benefits from the road, many of their families had slowly moved from the old village and mbaru gendang. Steenbrink (Steenbrink K., 2007) notes that since then, the people have struggled to question the power of the spirit and ancestors.

When the Dutch left Manggarai, the European Catholic missionaries continued the development program. The Church spread not only Catholicism but also did many 
infrastructures. When Indonesia became independent, practically until the 1960s, the Catholic Church was the essential institution for development in Flores, including in Manggarai. More schools, clinics, roads, home infrastructure, irrigation, and many others were built by Church rather than by the government. At the end of the 1970s, the government started (Widyawati \& Lon, 2021).

By the presents of the Catholic missionaries, the Manggarai people began to imitate the "the western's lifestyle" regarding the house's exterior and interior design. People liked simpler, smaller, more clean, modern, and private houses. They put many new household appliances such as tables, chairs, cabinets, other living room accessories, kitchen, and dining utensils inside the house. It was not surprising that people considered the large old mbaru gendang not ideal anymore. People perceived it as old and primitive.

With the arrival of Catholicism and the Indonesian government's, the new centers have no longer at the traditional village but rather at the market, churches, schools, and other public facilities. The village head with his apparatus has been no longer the sole authority of the territory ruler. From a ritual perspective, the role of the village head has shifted to Church's leader. Likewise, with the presence of a government, the arrangement of village life has no longer depended on the village head alone. It has moved to the government officials.

The government has offered a more complex life order, covering many aspects of people's lives. The state system has regulated people's lives in greater detail than the custom's one. The demands of modern life have forced traditional societies to follow governance and submit to new authorities and regulations. Thus, the role of adat and village head has become marginalized. The exact change happened to the power, function, and superiority of the mbaru gendang. After the fall of the Soeharto regime, during the reform era, the revitalization of adat became a significant change. People have been excited to revitalize symbols of the local culture. This echo also occurred in Manggarai. People gave more new attention to the mbaru gendang. Many people wanted the old traditional houses, the original ones, to be rebuilt in the villages. The construction of mbaru niang Wae Rebo, one of the villages currently a famous tourism icon in this region, was a "first wave project" of this revitalization (Widyawati \& Lon, 2021).

After seeing the success and beauty of the mbaru niang in Wae Rebo, the local government also programmed the revitalization of traditional houses in other villages. The government provided substantial funds to support the program. During the first decade of the 21st century, the village had been busy rehabilitating the new house. This movement was vivacious. It was as if one village was competing with another. It is interesting that electoral politics also has influenced change. Many candidates took the village's sympathy with direct elections by sponsoring the revitalization of the mbaru gendang. As a result, some villages rebuilt the house with those "political" sponsorship funds.

Contrary to the spirit of revitalization, unfortunately, during the latest decade, the study found that several mbaru gendangs have been empty. The village heads did not want to inhabit the house. How did this happen? What were the background and impact? The answers are as follows.

\subsection{Findings}

The study found several reasons why the village heads did not want to live inside the mbaru gendang anymore. The first and most common reason is regarding privacy and comfortable feeling. As previously explained, the mbaru gendang is a residence intended for more than one family. A family is only entitled to have one private bedroom. They have to share a family, dining, and kitchen room with whole families dwelling in the big house. 
Modern families considered this very hard. Today, every child wants to have a room. They neither want to share with their parents nor sleep with other children from other families in a shared room. It also regards the issue of protection from sexual abuses, especially for girls. People have considered it not good or dangerous for a girl to sleep in an open room sharing with other boys.

Likewise, in terms of household appliances, every family wanted to own property and home furnishings that make their life more comfortable and prestigious. If they stayed in the mbaru gendang, this was not easy. So, when the mbaru gendang was under construction as part of the revitalization program, those who initially lived in the mbaru gendang had the opportunity to leave the house. They moved to their own homes. When the construction was finished, they did not return to the house and still chose to stay in their own house. Moreover, many families considered staying at the mbaru gendang was not economical, wasteful of money. Once a village has to do a meeting, ritual or welcoming of guests, the family has to provide food and drink.

Another reason was the head of the village or clan working and living far from the village. Some even work outside the district and the island. In the past, most of the Manggarai were farmers. Nowadays, many people work not as a farmer. They work and live far from their village. Then they could not stay in the mbaru gendang anymore. The research found that there was also minor conflict between the families of the village heads. This conflict caused discomfort to live together in one house. There have been disagreements about who should stay in the house. Because of these reasons, some families felt safer staying in their house than dwelling in the mbaru gendang.

Another reason has to do with the feeling of having rights to land and houses. Since the mbaru gendang is public property, no family could claim it as their private property. Ownership of land and home is a natural thing that someone wants. This study also found that people made new agreements to function the house as merely as a building to hold village gatherings and meetings rather than as a home to stay. As a result, some new houses provide no bedroom at all but a single open large room.

When this research explored how people's perspectives on this phenomenon have been common answers, some people felt that the change was a cultural deviation that endangered local cultural identity. There should be an effort to maintain the original tradition. Otherwise, the values of culture may be lost. Nevertheless, some did not share the same idea. They saw the change as acceptable and reasonable. However, according to them, traditional houses have still been seen as symbols of local culture and identity. In addition, the house occupied by the family was considered livelier and more authoritative than the empty building. This made differences between a warm house and a cold building, a lively home, and a lonely functional building.

\section{Discussion}

The changing functions of several mbaru gendangs in Manggarai have become the focus of this research. Socio-anthropological studies have distinguished between a house and home and between home and building. Not all houses can be considered as homes (Easthope, 2010; Bille, 2017). A house can only be a house or more just a building. The warm aspect of the house indicates the existence of a family and interaction between the people. The house is also related to the memory that lives in each of its inhabitants. The house is unique because it is not a building but because of feelings, practices, and warm and open relationships. Home gives a sense of belonging. Home also represents a stronger community and family life (Perkins, H. C., Thorns, D. C., \& Winstanley, 2008). 
From the beginning, the Manggarai people positioned the mbaru gendang as a comfortable house and not as a mere physical building or structure. This house is the residence of not only humans but also the residence of ancestors and spirits. So, this house is sacred and alive at the same time. It is nourished by those who dwell and by the presence of a spirit power over this house. This study shows that village heads who do not want to live in traditional houses feel that living in traditional houses is no longer considered homey. Feelings of security and comfort are more experienced when they live in a private house than in a public house. So, they choose to leave the traditional house and look for a warmer taste in their own home so that the change of the new drum into a building and not a residence cannot be avoided.

This study captures that the family should live in a static private and family traditional house. They are not just personal presentations, and families represent the community or village. They are an autonomous family who also wants to live like most other families. They want to live in their own home, where they can manage their household more freely. This change is also not pleased with the concept of houses and buildings and a shift from communalism to individualism (Azadeh, M. A., \& Tavakoli, 2007). This characterizes changes in an agrarian society. Modernism causes people to be more concerned with private matters than public interests. It happens to the culture. People like to change their culture and even abandon some aspects of living in a better and more comfortable way. This research proved it. The way people perceived and attitude towards the mbaru gendang has changed according to the times.

\section{Closing}

Cultural change is a normal phenomenon. The causative factor can be from within, and it can also be from outside. This study found that in Manggarai, Flores, East Nusa Tenggara, traditional houses have changed from home residences to cultural buildings. As a consequence, the value of the traditional house has also changed. The study found several reasons why the village and clan head did not want to live in the house: living in their own house is more comfortable, more private, more economical, and they have the right to a home. In addition, there are conflicts between families and a new agreement from residents to make the mbaru gendang an empty building. Therefore, a cultural shift wants to carry out the comfort of a private family rather than just carrying out cultural mandates and ancestral heritage that are not necessarily comfortable for oneself.

The changes that occur do not stand alone. What happened in the local culture of Manggarai illustrates the cultural changes that are common in many places. The causes also relate to social, political, economic, and religious phenomena in other places in other situations and contexts. The recent change has an impact on the culture as well as for those who live in the house. Although this change has not been following the old custom, many parties can rationalize this change without losing their cultural identity. There have always been new negotiations and adaptations in the culture.

\section{References}

[1] Adams, K. M. (2003). The politics of heritage in Tana Toraja, Indonesia: Interplaying the local and the global. Indonesia and the Malay World, 31(89), 91-107. https://doi.org/10.1080/13639810304444 
[2] Adams, K. M. (2003). The politics of heritage in Tana Toraja, Indonesia: Interplaying the local and the global. Indonesia and the Malay World, 31(89), 91-107. https://doi.org/10.1080/13639810304444

[3] Adishakti, L. (2008). Community empowerment program on the revitalization of Kotagede Heritage District, Indonesia post-earthquake. Vulnerable Cities: Realities, Innovations and Strategies.

[4] Akram, OK, Franco, DJ, \& Ismail, S. (2016). The cultural significant of erbil city: case of traditional kurdistan houses. International Journal of Engineering Technology, Management and Applied Sciences.

[5] Allerton, C. (2003). Authentic housing, authentic culture? Transforming a village into a "tourist site" in Manggarai, Eastern Indonesia. Indonesia and the Malay World, 31(89), 119-128. https://doi.org/10.1080/13639810304440

[6] Allerton, C. (2009). Static crosses and working spirits: Anti-syncretism and agricultural animism in Catholic west Flores. Anthropological Forum, 19(3), 271-287. https://doi.org/10.1080/00664670903278403

[7] Antar Yori. (2010). Pesan dari Waerebo.

[8] Azadeh, M. A., \& Tavakoli, A. (2007). Individualism, communalism and religiosity. Quarterly of Cultural Studies \& Communication.

[9] Dalkılıç, N., \& Nabikoğlu, A. (2020). Documentation and analysis of structural elements of traditional houses for conservation of cultural heritage in Siverek (Şanliurfa, Turkey). Frontiers of Architectural Research, 9(2), 385-402. https://doi.org/10.1016/j.foar.2019.11.003

[10] Darmayanti, T. (2016). The Ancestral Heritage: Sundanese Traditional Houses of Kampung Naga, West Java, Indonesia. MATEC Web of Conferences.

[11] Du Cros, H \& McKercher, B. (2014). Cultural Tourism.

[12] Erb Maribeth. (1999). The Manggaraians: A guide to Traditional Lifestyles.

[13] Gunce Kagan and Damla Misirlisoy. (2019). Assessment of Adaptive Reuse Practices Through User Experiences: Traditional Houses in The Walled City of Nicosia. Sustainability.

[14] Hanan, H., Suwardhi, D., Nurhasanah, T., \& Bukit, E. S. (2015). Batak Toba Cultural Heritage and Close-range Photogrammetry. Procedia - Social and Behavioral Sciences, 184(May 2016), 187-195. https://doi.org/10.1016/j.sbspro.2015.05.079

[15] Hardilla, D., \& Nugroho, A. C. (2018). The Role of Internet of Things to Support Cultural Heritage Inventory in Urban Resiliency Approach: Tradisional House in Bandar Lampung Case. 2018 International Conference on Information Technology Systems and Innovation, ICITSI 2018 - Proceedings, 193-198. https://doi.org/10.1109/ICITSI.2018.8695935

[16] Knapp RG. (2012). Chinese Houses: The Achitectural heritage of a nation.

[17] Liangwen, Z. (2006). Studying Tradition Deeply and Protect Essence Clearly — The Consideration in Formulating of "The Maintain Technical Manual for the Protection of the Traditional Houses in World Cultural Heritage the Old Town of Lijiang."

[18] Lon, Y. S. (2015). Tantangan inovasi pendidikan dan budaya di manggarai. Fenomena Mbaru Gendang Di Manggarai.

[19] Mackey. (2002). The house of difference: Cultural politics and national identity in Canada.

[20] Milligan, M. (2003). Displacement and identity discontinuity: The role of nostalgia in establishing new identity categories. Symbolic Interaction.

[21] Noviarti, Irsa, R., \& Masdar, A. (2013). Preserving Minangkabau Traditional Building in West Sumatera, Indonesia: Integration of Information Technology. Procedia Environmental Sciences, 17(December), 749-756. https://doi.org/10.1016/j.proenv.2013.02.092 
[22] Perkins, H. C., Thorns, D. C., \& Winstanley, A. (2008). House and home: Methodology and methods for exploring meaning and structure. Qualitative Housing Analysis: An International Perspective.

[23] Rasdi, M. (2005). The architectural heritage of the Malay world: The traditional houses.

[24] Steenbrink K. (2007). Catholics in Indonesia, 1808-1942: A Documented History.

[25] Timothy, D. J. (2021). Cultural heritage and tourism.

[26] Widyawati, F., \& Lon, Y. S. (2021). The catholic church and the covid-19 pandemic case study of bishop ordination in Ruteng, Flores, Indonesia. Journal of Law, Religion and State, 8(2-3), 298-308. https://doi.org/10.1163/22124810-2020011 